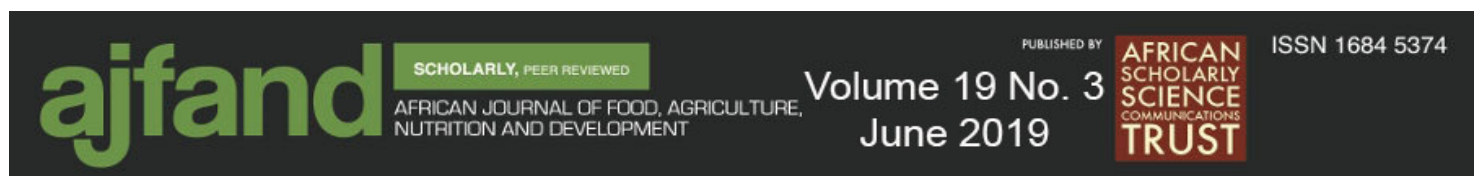

Afr. J. Food Agric. Nutr. Dev. 2019; 19(3): 14587-14601

DOI: 10.18697/ajfand.86.18025

\title{
THE RELATIVE CONTRIBUTIONS OF CEREAL PRODUCTION, IMPORTS, AND AID TO SOMALI FOOD SECURITY
}

\section{Gavin $\mathbf{R}^{1}$, Haji $\mathbf{H}^{2}$ and P Porter ${ }^{1 *}$}

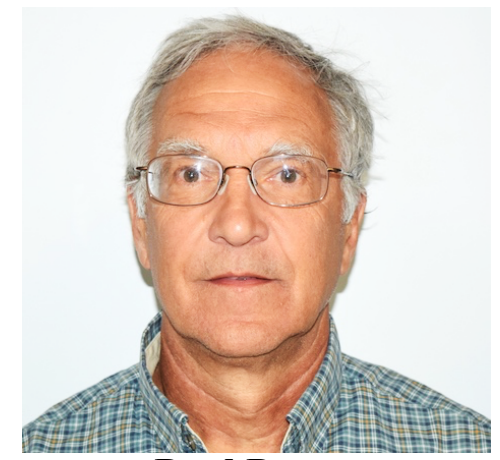

\section{Paul Porter}
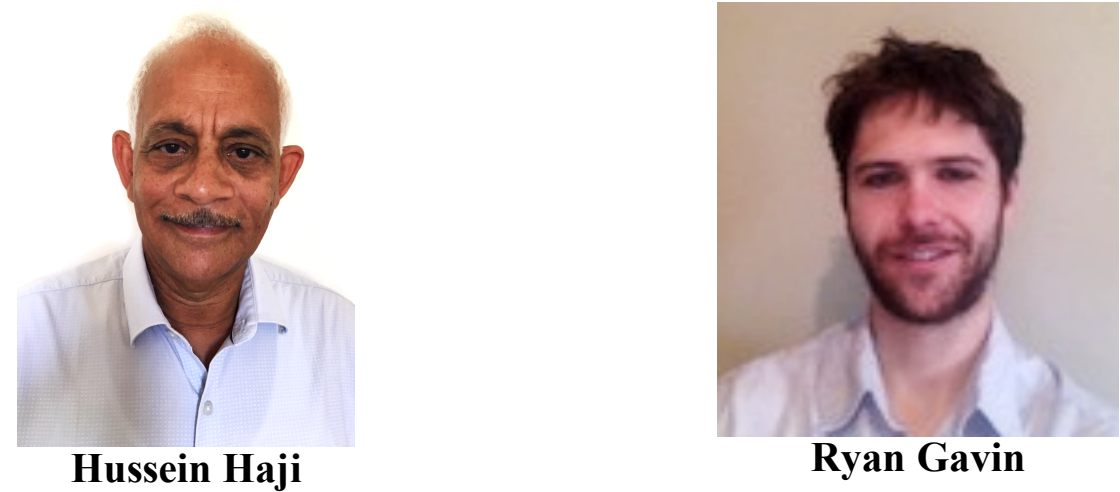

*Corresponding author email: pporter@umn.edu

${ }^{1}$ Department of Agronomy \& Plant Genetics, 411 Borlaug Hall, University of Minnesota, 1991 Upper Buford Circle, St. Paul, 55108, MN, USA

${ }^{2}$ SATG, Somali Agriculture Technical Group, Safari Complex, Km5 Road, Hodan District, Mogadishu, Somalia 


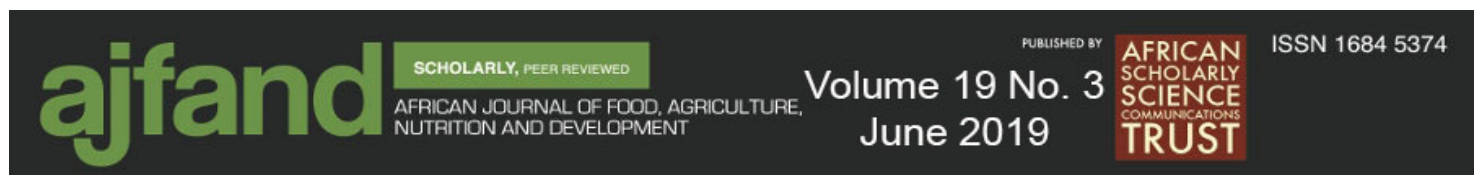

\section{ABSTRACT}

Somalia is among the poorest countries on the planet. Since the fall of Siad Barre's regime in 1991, the country has been in a near-constant state of food insecurity and suffered two officially declared famines. In order to address the issue of food insecurity in Somalia, a greater understanding of each of the components that contribute to the Somali food supply is merited. Cereal crops make up a third to half of the Somali diet by calories and are among the most important food crops produced by the country. This study investigated the historic trends in domestic cereal production, cereal imports, and food aid (reported in cereal equivalents) in Somalia by exploring secondary data publicly available from the Food and Agriculture Organization (FAO) of the United Nations, and the World Food Programme. These data were related to World Bank population data in Microsoft Excel and average per capita production, import, and aid figures were calculated. Median changes over time and their associated interquartile ranges were reported. The data demonstrated that Somali cereal production levels have not improved since the 1960's, and since that time, they have been characterized by an extreme amount of year-to-year volatility. Moreover, maize and sorghum are the only meaningful fractions of Somalia's domestic cereal production, and recent total production of each crop is well below the levels observed in the 1980's. When combined, per capita production of maize and sorghum has decreased precipitously over time (falling from a high of $91 \mathrm{~kg}$ per capita in 1972 to just $30 \mathrm{~kg}$ per capita in 2012). This is likely due to a combination of stagnant production and rapidly increasing Somali population (up over $350 \%$ since 1961). This has increased the importance of cereal imports and aid to Somalia and has made the country vulnerable to disruptions in international cereal markets and foreign government policies. Improving domestic cereal production in Somalia should be part of any future food security strategy for the country. Recent agricultural research in Somalia suggests that the implementation of simple agricultural best management practices can increase cereal production in the country.

Key words: Somalia, Population Growth, Cereal Production, Cereal Imports, Food Aid 


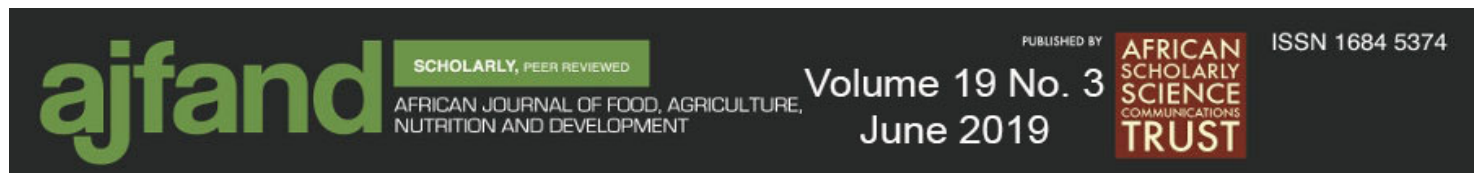

\section{INTRODUCTION}

Political and civil unrest have hindered Somalia's economic development since the fall of the Siad Barre regime in 1991 [1]. This instability has resulted in high mortality rates, a lack of public services, and a near-constant state of food insecurity for much the Somali population [2]. In just the past two decades, Somalia has faced two officially-declared famines (1992 and 2011) [3,4]. These famines, which combined have resulted in over half a million deaths $[5,6]$, are often attributed to drought and failures of domestic crop production [5,7]. While this paper does not refute the assertion that Somali crop production suffered enormously during the 1992 and 2011 famine years and that these failures contributed to the famines, it does seek to better illustrate the historical crop production and food availability context in which these failures occurred. This paper will further demonstrate that Somali food security has been extremely tenuous for many years and that increasing and stabilizing domestic crop production could help to stabilize Somalia's food security.

There are many different interpretations of what constitutes food security [8]. The Food and Agriculture Organization of the United Nations (FAO) has officially declared food security to be a state in which "all people, at all times, have physical and economic access to sufficient safe and nutritious food to meet their dietary needs and preferences for a healthy and active life [9]." Within the FAO's definition of food security, it is clear that food security is a function of many interrelated factors including population growth, domestic cereal production, cereal imports and food aid. Historically, cereals constitute 30 to $50 \%$ of the Somali diet (by calories) and are among the most important foods and economic crops produced in Somalia [10]. Therefore, the focus of this paper is to explore the complicated relationships that exist between cereal production, imports, and food aid in Somalia and examine how these relationships impact Somali food security.

\section{METHODOLOGY}

The secondary data used in this analysis were assembled for analysis using the data generation services of major international agricultural and development organizations. The human population data for this paper was sourced from the World Bank Group's (WBG) open data portal (1961 to 2012) [11]. Data on domestic cereal production (total production, harvested area, and crop yield) and cereal imports were accessed from the FAO's corporate statistical database "FAOSTAT" (1961 to 2012) [12]. Because the crop yield figures generated by FAOSTAT are implicit, being derived by taking the quotient of the total crop production estimates and the known crop area harvested [13], the primary focus of this investigation was on the historic trends in crop production and harvested area, rather than crop yields.

For the purposes of analysis, we define cereal as maize, sorghum, rice, and wheat. Although farmers in Somalia produce all of these crops, only maize and sorghum make up any meaningful fraction of domestic cereal production [12]. The domestic cereal production figures were generated by summing FAOSTAT maize and sorghum production data and the total imported cereal figures were created by summing FAOSTAT data on maize, sorghum, rice and wheat production. The FAOSTAT system 


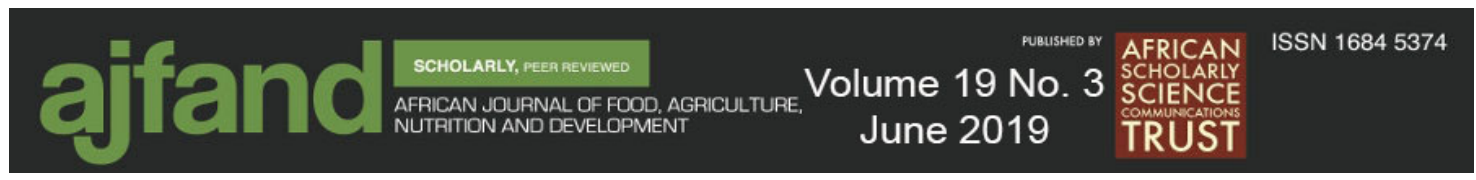

focuses on annual data and does not characterize within-year seasonal differences in crop production, and it should be noted that this approach can be problematic when assessing food security or planning interventions because annual production data may mask seasonal food shortages. In Somalia, for example, there are typically two cereal production seasons each year - the $\mathrm{Gu}$ and the Deyr -, and these seasons differ significantly in their contributions to annual crop production [14].

Annual food aid delivery data from 1988 to 2012 were collected in the form of cereal equivalents using the World Food Programme (WFP)'s Food Aid Information System [15]. Total cereal availability in a given year was determined as the sum of total domestic cereal production, imports, and aid in cereal equivalents in that year. While this interpretation does not factor in the effects of cereal storage, these effects likely do not contribute meaningfully to the Somali cereal supply annually given the high percentage of post-harvest losses estimated in Somalia [16] and the extremely low levels of annual per capita cereal availability observed in this analysis.

Per capita cereal production data were created by relating FAOSTAT crop production data with WBG population data. For the majority of the datasets described in this analysis, average trends over time are described using the median as the measure of central tendency and the interquartile range (IQR) as the measure of data variability. The reason for this approach is that the median is less likely to be influenced by extreme data points and a high degree of annual variability in these historic datasets was observed. Finally, given the difficult reporting conditions in Somalia, it should be remembered that the publicly available data from these sources are best estimates, and because the datasets on these websites are subject to change, it is important to note that the numbers presented here were obtained in August of 2017.

\section{RESULTS AND DISCUSSION}

\section{Human Population trends in Somalia since the 1960s}

The population of Somalia has increased dramatically since the 1960's (Figure 1). In 1961, the WBG's estimate of the Somali population was around 2.8 million persons. In 2012, that number had risen to over 12.8 million - an increase of over $350 \%$ [11]. It should be noted, however, that these numbers are only estimates, as the most recently available data produced by the Somali government were from a 1975 census [17], and it was not until 2014 that a United Nations Funded Survey was completed. There is no doubt, however, that the Somali population has grown rapidly over the last half century. Between 1961 and 2012, the median annual population growth rate was 3\% [11]. These rates ranged from single-year increases of 13\% (1976-1977) to single-year increases of less than 1\% (1983-1984), with an interquartile range (IQR) of just $1 \%$. The extreme values in this range seem to coincide with periods of political and social uncertainty and development [1], respectively. It is interesting to note that even in the years surrounding the 1992 and 2011 famines, the Somali population continued to increase annually. 

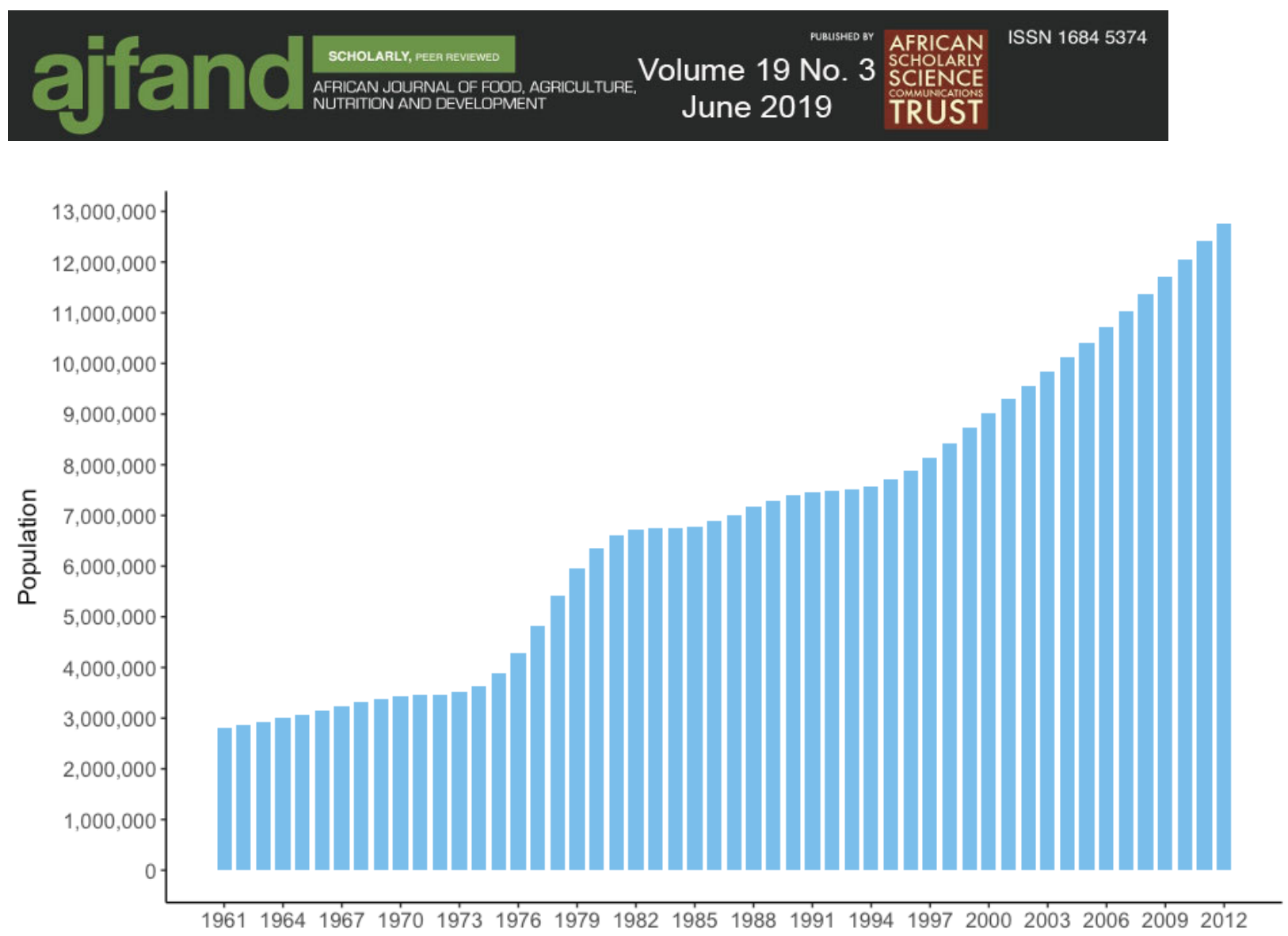

Figure 1: The Somali population from 1961-2012 based on WBG data [11]

\section{Cereal Production trends in Somalia since the 1960s \\ Maize}

The Shebelle riverine is Somalia's most important maize producing region [18]. Though data regarding specific maize production practices in the region are scanty, traditionally most maize in the Shebelle riverine is open-pollinated and grown under furrow irrigation with little to no use of external fertilizers or mechanical implements [19]. These production practices are, in many ways, less sophisticated than those advocated under the relative stability of the Siad Barre regime, when a concerted rural development strategy was adopted [20].

Between 1961 and 2012, neither total harvested maize area (Figure 2) nor total maize production (Figure 3) changed appreciably in Somalia. However, in each case, an extreme amount of year-to-year volatility was observed [12]. Annual rates of change for total maize harvested area ranged from a single-year reduction of 64\% (1990-1991) to a single-year increase of 353\% (1993-1994), with a median annual rate of change of $0 \%$ (1961-2012). This year-to-year volatility in total maize harvested area is reflected by the annual volatility observed for total maize production. Annual rates of change for total maize production ranged from a single-year reduction of $68 \%(1990-1991)$ to a singleyear increase of $122 \%$ (2011-2012), with a median annual rate of change of $0 \%$ (19612012). The IQR of annual rates of change for both total harvested maize area and total maize production was $14 \%$.

The volatility in total maize harvested area and total maize production are probably not attributable to any single factor. A combination of unsophisticated farm management 


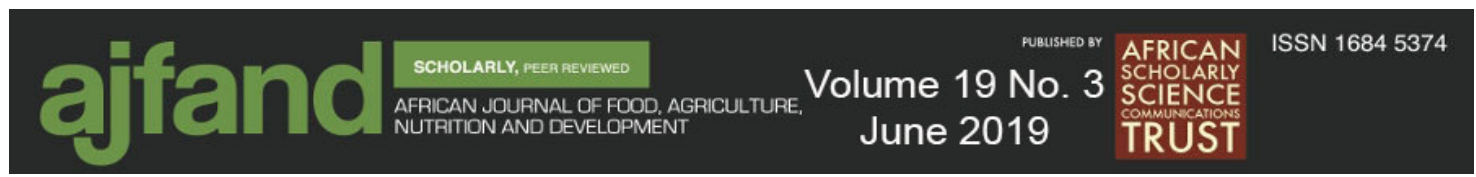

practices in traditional maize cropping systems $[14,19,20]$, consistent political instability [1,5], and harsh environmental conditions - especially drought [7] and flooding — are all potential drivers of the volatility observed in domestic maize production. Unsurprisingly, for total maize area harvested and total maize production, the most extreme annual rates of change occurred in years surrounding the famine years (1992, 2011). One interesting observation is that total maize production spiked dramatically and peaked in the mid to late 1980s. These gains may have partially stemmed from the Barre regime's adoption of a National Rural Development Strategy in 1979, which specifically emphasized increasing cereal production [20].

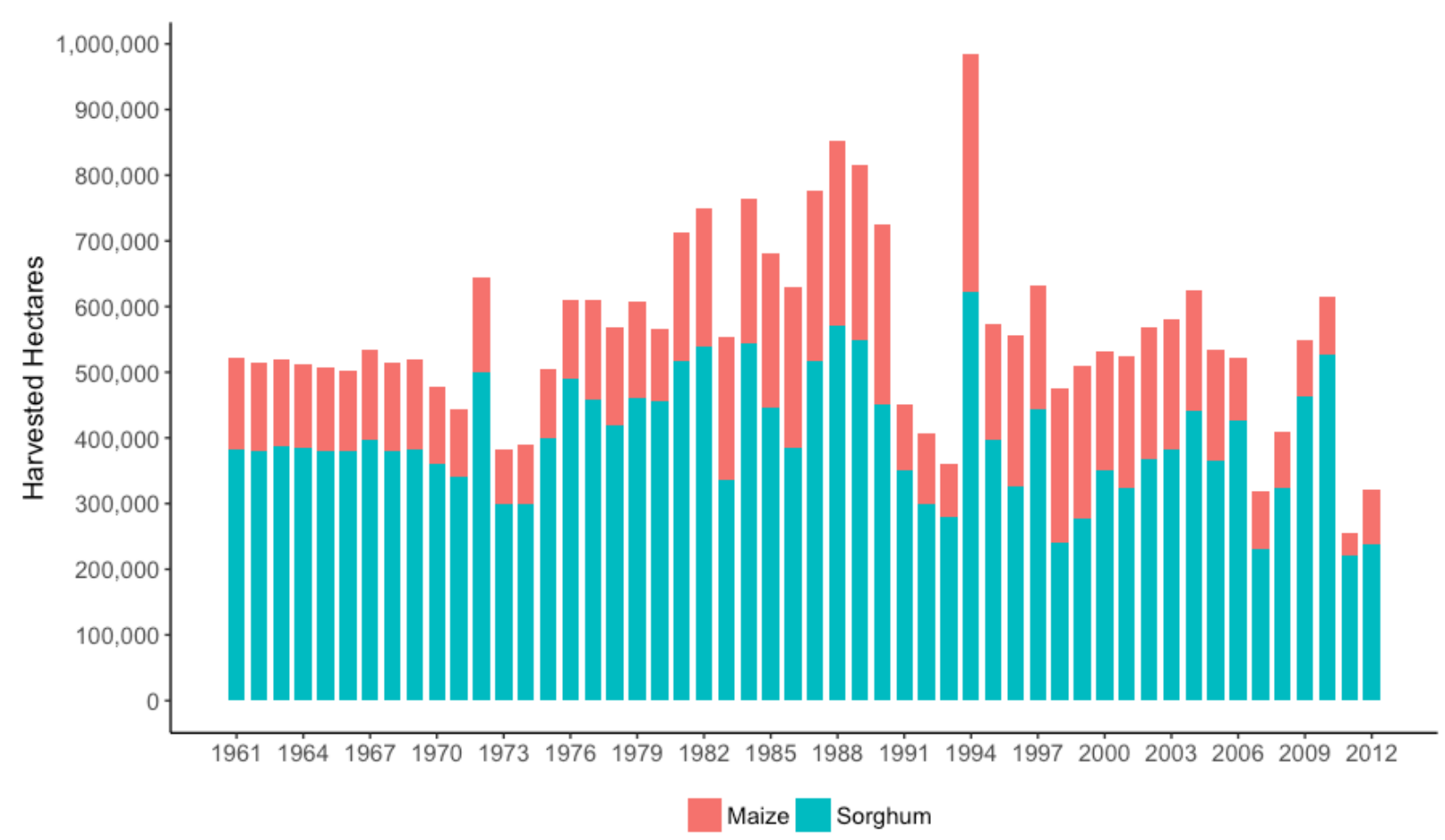

Figure 2: Harvested hectares of maize and sorghum in Somalia from 1961 to 2012 based on FAOSTAT data [12] 

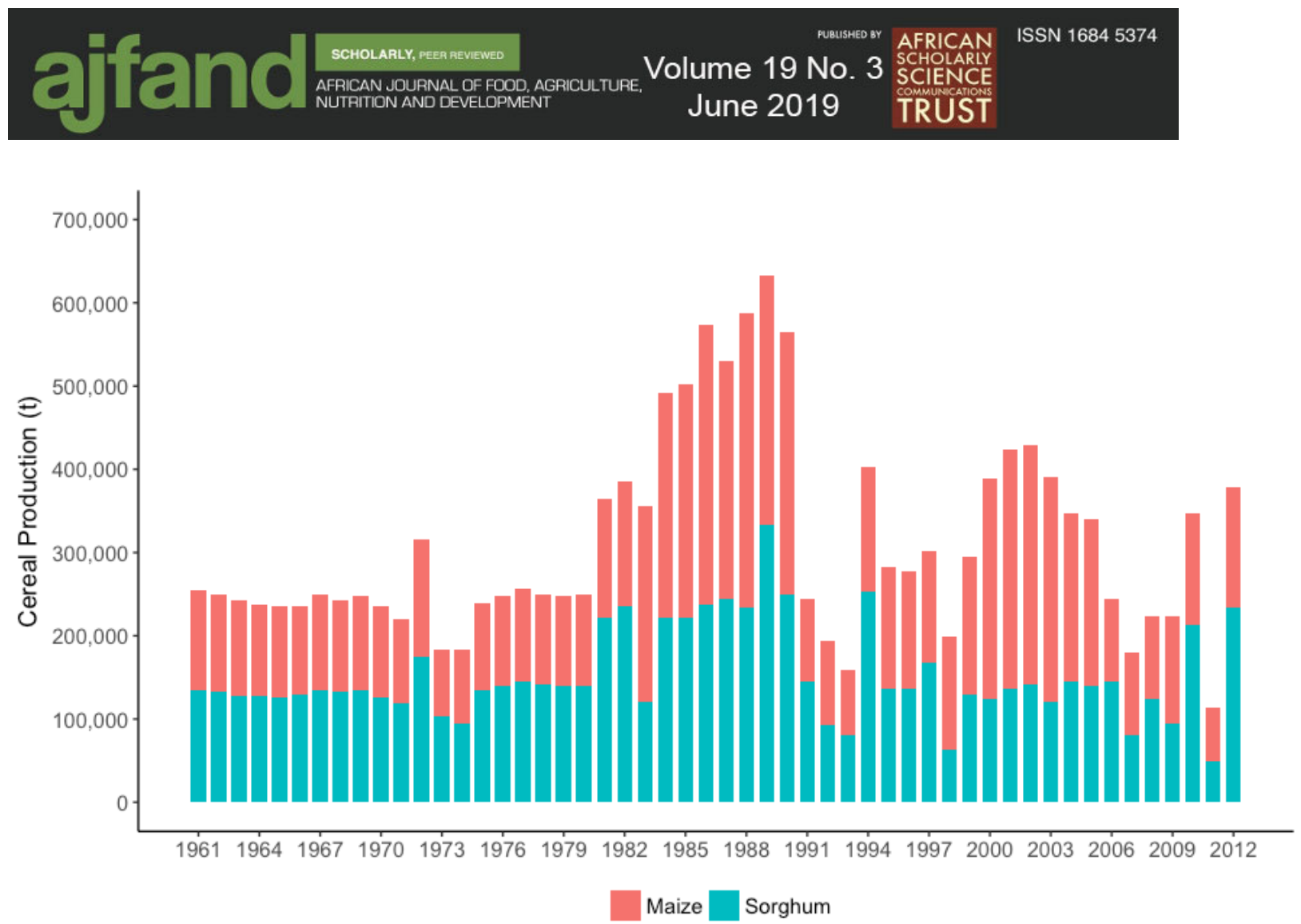

Figure 3: Total maize and sorghum production in Somalia from 1961 to 2012 based on FAOSTAT data [12]

\section{Sorghum}

Unlike maize, which dominates the irrigated farmland of the Lower Shebelle River, sorghum production in Somalia is rain-fed, and the majority of sorghum production takes place in the central Bay region [13]. Like the total harvested maize area and total maize production, sorghum production in Somalia has been highly volatile and failed to improve since the 1960's (Figures 2 and 3) [12]. In the last 50 years, annual rates of change for total sorghum harvested area ranged from a single-year reduction of 58\% (2010-2011) to a single-year increase of 122\% (1993-1994), with a median annual rate of change of $0 \%$ (1961-2012). Again, year-to-year volatility in total harvested sorghum area is reflected in the volatility observed in annual rates of change for total sorghum production. For total sorghum production, annual rates of change ranged from a singleyear reduction of $77 \%(2010-2011)$ to a single-year increase of $382 \%(2011-2012)$, with a median annual rate of change of $0 \%$ (1961-2012). The IQR of annual rates of change for total harvested sorghum area and total sorghum production were $25 \%$ and $16 \%$, respectively.

The bulk of the volatility observed for total sorghum area harvested and total sorghum production can be explained by the same factors that increased the total maize harvested area and total maize production volatility. However, more of the volatility observed for sorghum production may be attributable to environmental conditions than for maize production. This is because, unlike maize which is normally produced under furrow irrigation, sorghum production in Somalia takes place in the drylands and is almost entirely rain-fed, making it highly dependent on timely rainfall. 


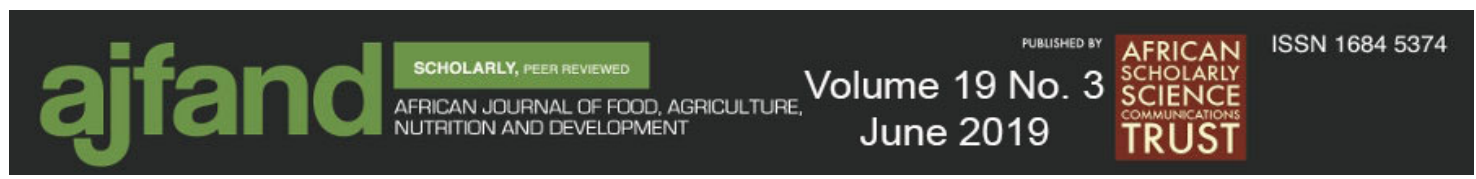

\section{Maize vs. Sorghum}

A larger area of land is dedicated to sorghum production in Somalia than to maize production (Figure 2). Between 1961 and 2012, the total harvested sorghum area was $180 \%$ greater than the total harvested maize area when the medians were compared. This observation, however, was subject to a great amount of year-to-year volatility, with same-year differences ranging from as low as $1 \%$ greater sorghum harvested area (1998) to over $500 \%$ greater harvested sorghum area (2011) and an IQR of $126 \%$ for these differences. Although more land is dedicated to sorghum production in Somalia, sorghum and maize contribute similarly to the Somali food supply. In terms of total crop production between 1961 and 2012, the annual total sorghum production was only 13\% greater than that of the annual total maize production when the median was calculated. Though less volatile than when total crop areas harvested were compared, the amount that sorghum production exceeded maize production annually was also wide-ranging (Figure 3). Between 1961 and 2012, a range of 55\% less total sorghum production than total maize production (2003) and 68\% more total sorghum production than total maize production (1998) was observed, with an IQR of $48 \%$ for these differences. The fact that substantially more land must be dedicated to dryland sorghum production than to irrigated maize production in order to achieve similar total production in Somalia is consistent with other historic analyses performed in the United States, which demonstrated that irrigated maize yields are consistently greater than dryland sorghum yields [21].

\section{Per Capita Cereal Production and People Per Harvested Cereal Hectare}

Clear trends emerge when total cereal area harvested and total cereal production data are related to population estimates. The number of people supported per harvested cereal hectare increased between 1961 and 2012 (Figure 4) and per capita cereal production markedly declined (Figure 5). During the same period (1961 and 2012), the median annual rate of change for total cereal production per capita was negative 4\%. Annual rates of change for total cereal production per capita in these years ranged from a singleyear decrease of $68 \%$ (2010-2011) to a single-year increase of $224 \%$ (2011-2012), with an IQR of $16 \%$. In that same period, the median annual increase in the number of people supported by each harvested cereal hectare was 3\%. Annual rates of change for the number of people supported by each harvested cereal hectare ranged from a single-year decrease of $63 \%$ (1993-1994) to a single-year increase of $147 \%(2010-2011)$, with an IQR or $29 \%$. Unsurprisingly, the extremes of both of these ranges were observed in the years surrounding the famine years (1992 and 2011). The wide IQRs observed for total cereal production per capita and the number of people supported by each harvested cereal hectare are the results of the abovementioned annual volatility in total maize and sorghum production and total maize and sorghum area harvested, as annual population growth was consistent over that time frame. 

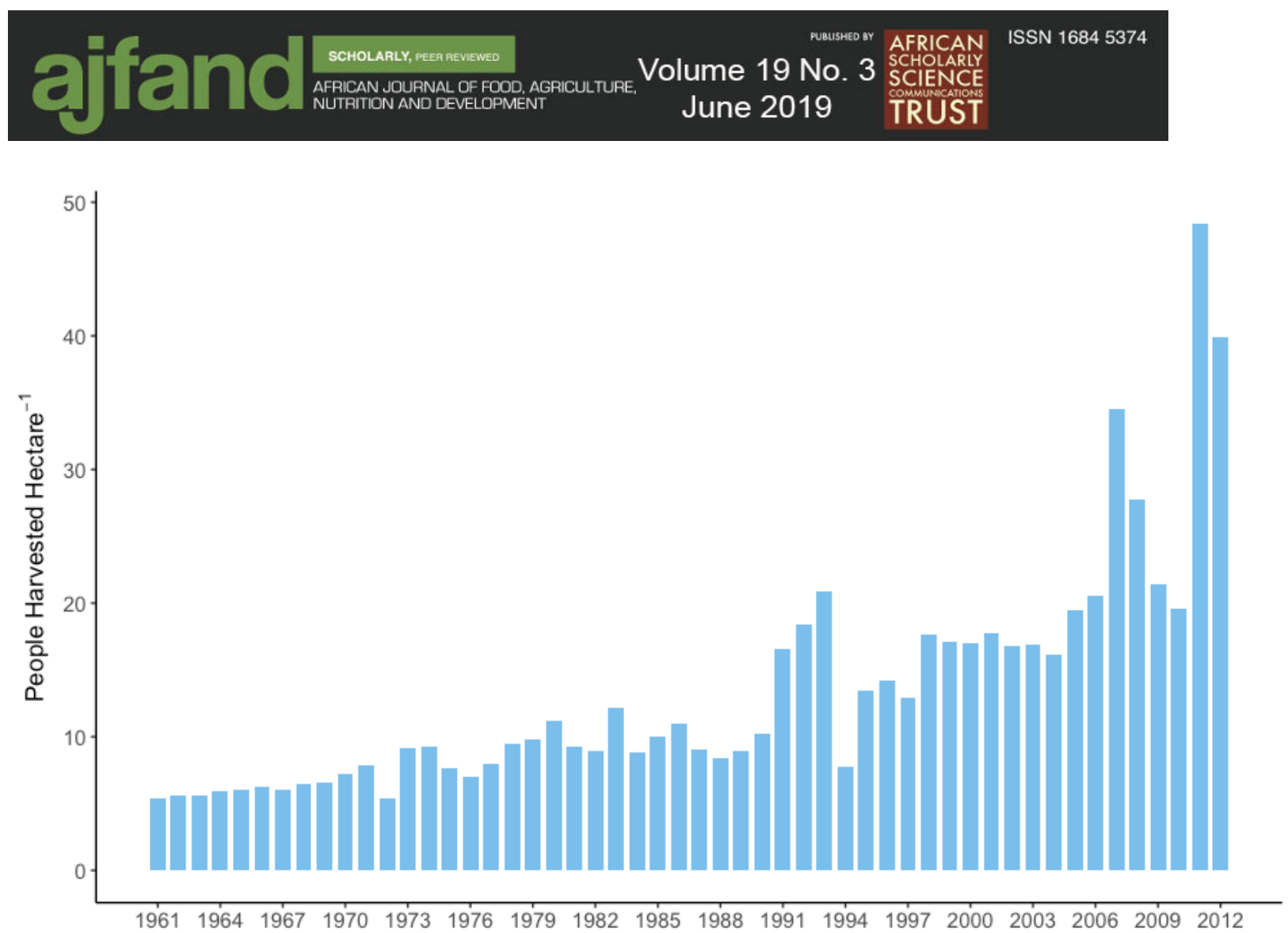

Figure 4: The number of people being supported per harvested cereal hectare from 1961 and 2012 based on FAOSTAT and WBG data $[11,12]$

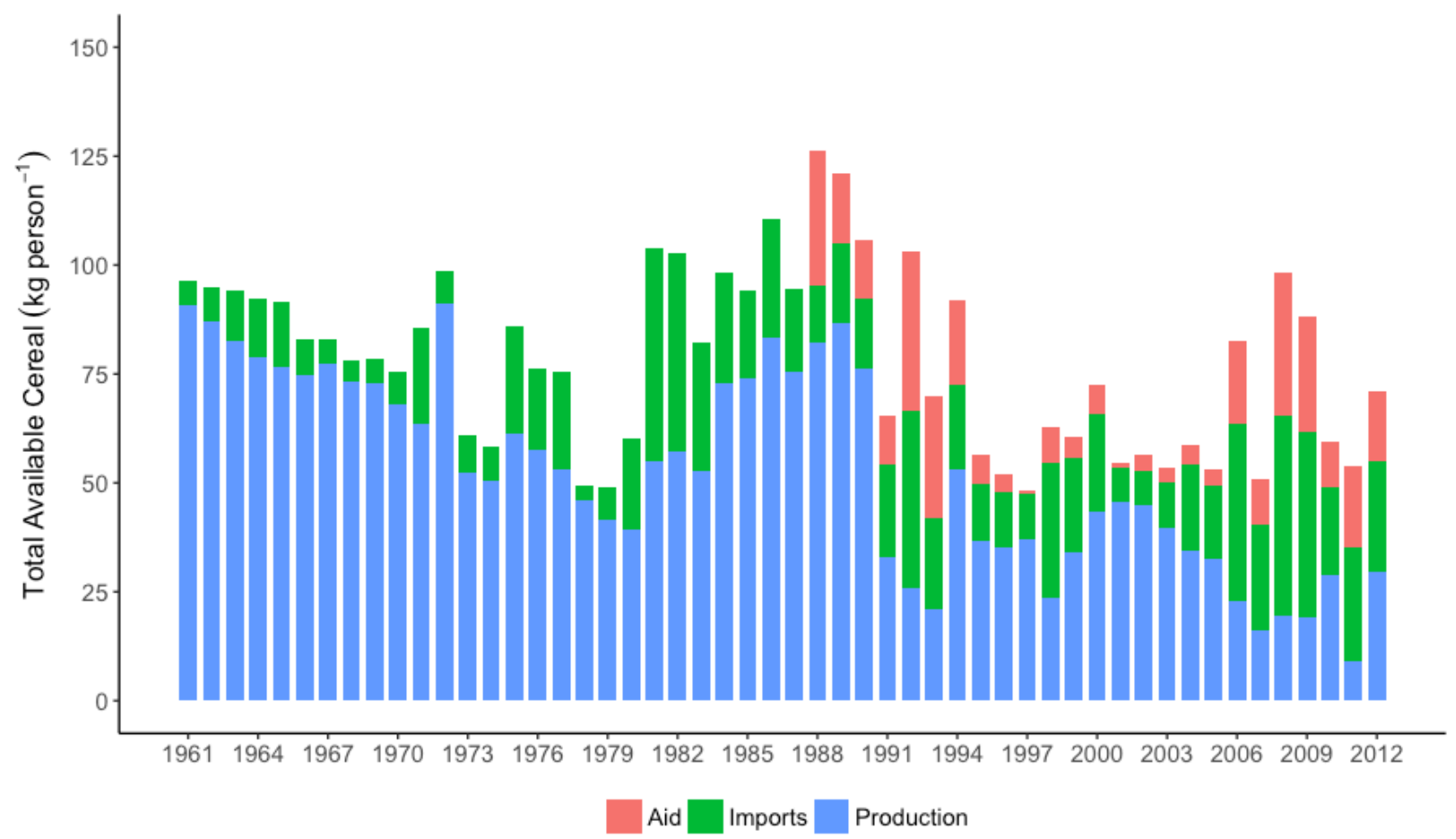

Figure 5: Total available cereal [comprised of total domestic cereal production, cereal imports, and food aid in cereal equivalents (1988-2012)] per capita from 1961 to 2012 based on FAOSTAT, WBG, and WFP data [11,12,15] 


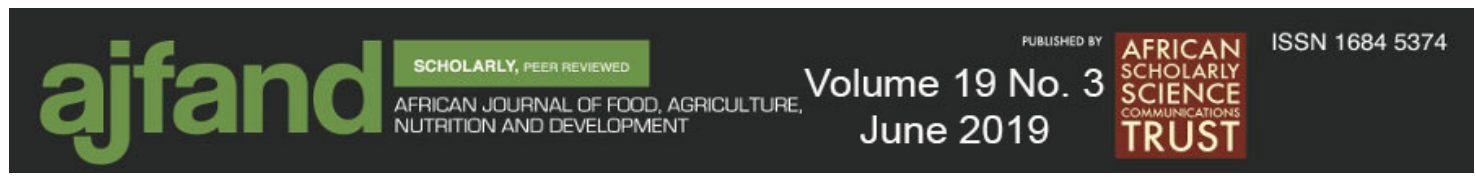

\section{Cereal Imports and Food Aid}

Cereal imports and food aid are completely distinct from each other. Cereal imports describe extra-territorially produced cereal grain that is brought into a country to be sold in the marketplace at market value. In contrast, food aid can be described as foodstuffs that are supplied to a population at no or reduced cost or in food-for-work or food-foreducation schemes. Like total domestic cereal production, the amount of cereal imported into Somalia annually between 1961 and 2012 was highly volatile (Figure 6) [12]. During this time, the median annual change in total cereal imports was $0 \%$, but the annual change in total cereal imports ranged from a single-year decline of 83\% (1977-1978) to a single-year increase of $237 \%$ (1974-1975), with an IQR of $60 \%$. However, while total domestic cereal production failed to increase between 1961 and 2012, several single-year increases in the amount of cereal imported resulted in a positive trend in annual cereal import rates, such that the mean annual change in cereal imports was an increase of $25 \%$ between 1961 and 2012. Year-to-year changes in cereal imports per capita closely reflected these changes (Figure 5).

Similarly, as a percentage of domestic cereal production between 1961 and 2012, cereal import amounts were highly variable, ranging from as low as 6\% (1961) to as high as $284 \%$ (2011), with a median of 34\% of the domestic cereal production level and an IQR of $48 \%$. Annually, the ratio of cereal imports to domestic cereal production fluctuated widely. Between 1961 and 2012, the year-to-year change in imports as a percentage of domestic cereal production ranged from a single-year decrease of 82\% (1977-1978) to a single-year increase of $372 \%$ (1997-1998), with an IQR of $83 \%$ and a median annual decrease of $2 \%$.

While volatility in domestic cereal production and in cereal imports does not support long-term food security, volatility in food aid is to be expected as food aid is meant to overcome immediate food shortages in the short term and not meant to be an enduring component of a country's food supply. In Somalia, however, food aid has become a major contributor to the country's food supply [15]. Since 1988, as a percentage of domestic cereal production, food aid (reported in cereal equivalents) has ranged from $2 \%$ (1996-1997) to $205 \%$ (2010-2011), with an IQR of 50\% and a median annual percentage of domestic cereal production of $34 \%$. This can lead to a situation of dependence that can be disastrous if food aid deliveries become unpredictable. In Somalia, these deliveries have been highly volatile. Between 1988 and 2012 (Figure 6), the annual rate of change in food aid deliveries (reported in cereal equivalents) ranged from a single year decrease of $84 \%$ (2000-2001) to a single-year increase of 1262\% (1997-1998), with an IQR of $102 \%$ and a median annual decrease of $16 \%$. However, as was the case with cereal imports, several extremely large single-year increases in food aid delivery rates resulted in a mean annual increase of 82\% between 1988 and 2012. Year-to-year changes in food aid deliveries per capita closely reflected these changes (Figure 5), and it has been observed that food aid availability may have been a contributing factor contributed to the 2011 famine [4]. 

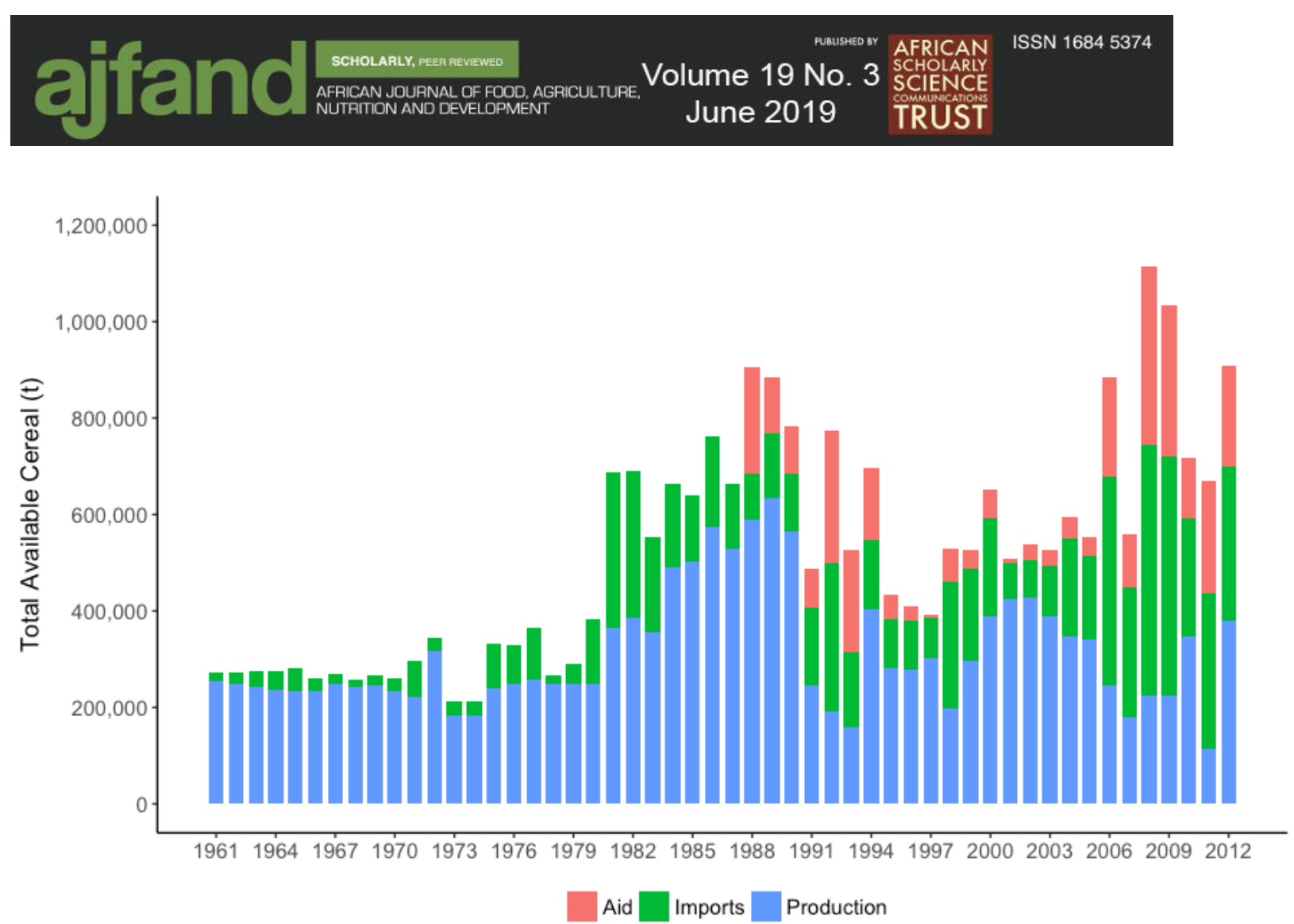

Figure 6: Total available cereal [comprised of total domestic cereal production, cereal imports, and food aid in cereal equivalents (1988-2012)] in real terms from 1961 to 2012 based on FAOSTAT, WBG, and WFP data $[11,12,15]$

\section{Total Cereal Availability}

Between 1988 and 2012, the importance of total annual domestic cereal production, total cereal annual imports, and total annual food aid (cereal equivalents) varied greatly (Figure 7). Domestic cereal production was consistently the most important contributor to total available cereal in Somalia (median of 58\%), but its annual contribution was variable, ranging from 17\% (2011) to 84\% (2001) with an IQR of 36\%. Cereal imports were the second most important contributor to total cereal availability in Somalia. Annually, they made a median contribution of $31 \%$, with total contributions ranging from $11 \%$ (1988) to $50 \%$ (1998) and with an IQR of $19 \%$. Finally, food aid, which is not meant to be a significant or enduring component of the food supply, made a median annual contribution of $13 \%$ to total cereal availability, ranging from as low as $1 \%$ (1997) to a high of over $40 \%$ (1993) and with an IQR of $16 \%$.

During this time (1988 to 2012), total annual cereal availability in Somalia was unpredictable and decreased on average (Figure 6). In real terms, total cereal availability in Somalia ranged from a single-year decrease of 38\% (2007-2008) to a single-year increase of $99 \%$ (2007-2008), with an IQR of 40\% and a median annual decrease of 5\%. These trends were reflected when per capita data were examined (Figure 5), but they exhibited slightly less variability (IQR of 38\%) and a slightly greater median annual decrease $(6 \%)$. When total available cereal data were explored for the years prior to food aid deliveries (1961 to 1987; including only domestic cereal production and cereal imports) (Figure 6), annual total cereal availability ranged from a single-year decrease 


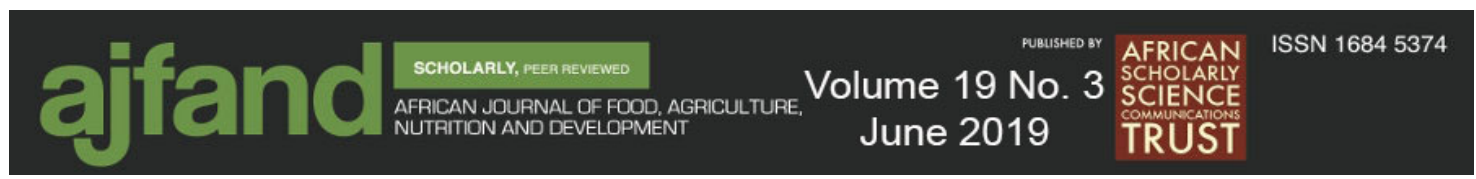

of $38 \%$ (1972-1973) to a single-year increase of $80 \%(1980-1981)$. These data had an IQR value of 18 and a median annual growth rate of $2 \%$. Any real gains, however, were offset by population growth (Figure 5), resulting in a per capita cereal availability during these years that was slightly more variable (IQR of 19\%) and demonstrated no median annual change $(0 \%)$.

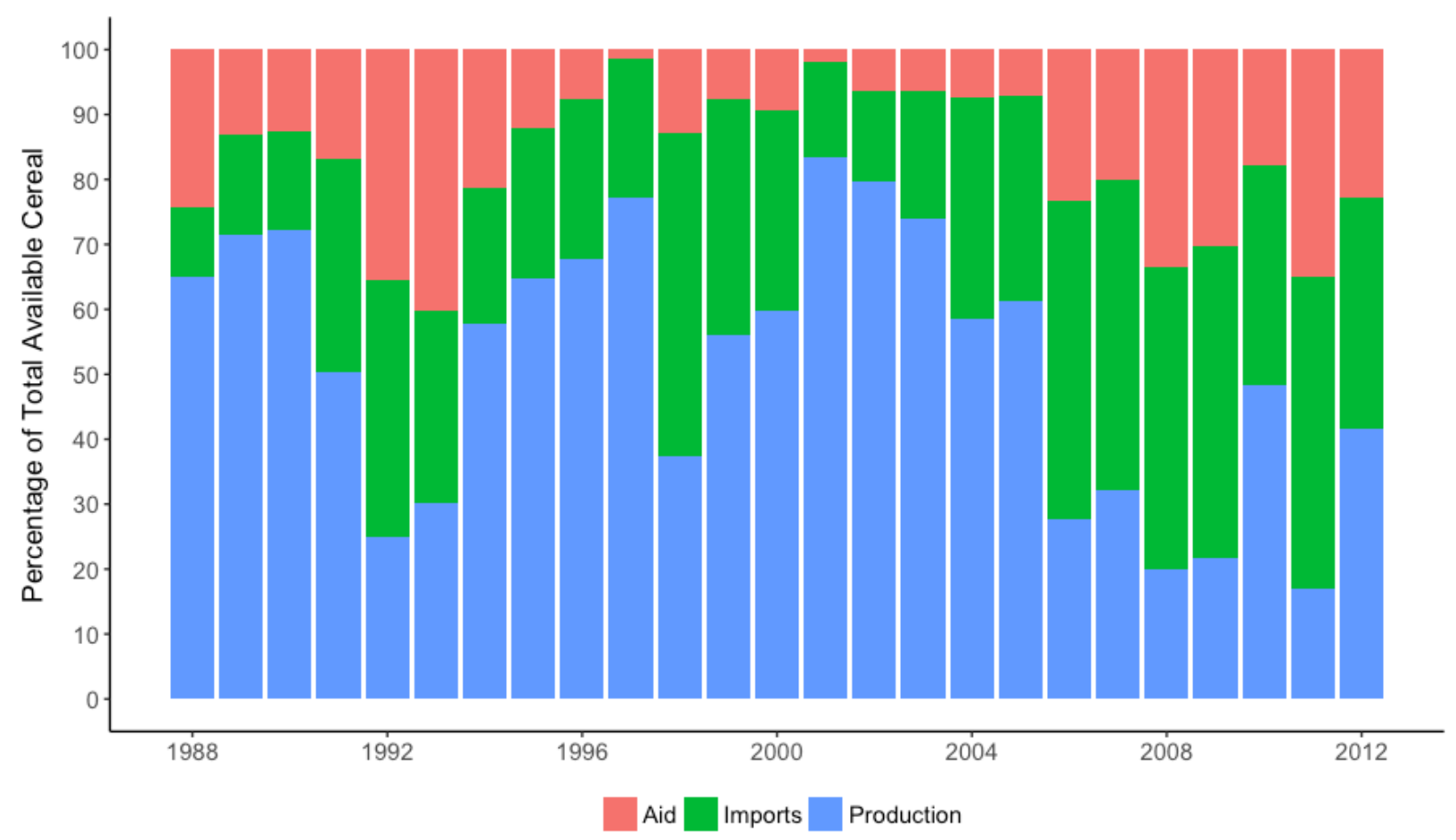

Figure 7: Total domestically produced cereal, cereal imports, and food aid (cereal equivalents) as a percentage of total available cereal [comprised of total domestic cereal production, cereal imports, and food aid in cereal equivalents] from 1988 to 2012 based on FAOSTAT and WFP data [12,15]

\section{Domestic Cereal Production as a Potential Solution}

While domestic cereal production has consistently been an important contributor to total cereal availability in Somalia, the above analyses have illustrated its annual instability and low productivity. One way to improve the food security situation in Somalia is to increase domestic cereal crop production and reliability. This can be done through the adoption of relatively simple agricultural management techniques that have been wellresearched and recognized as important yield factors in sub-Saharan Africa [22]. Until recently, little agricultural research had been performed in Somalia since the fall of the Siad Barre regime in 1991. New data, however, suggests that the adoption of a suite of mineral fertilizers, proper land and irrigation management techniques, and a denser planting population can result in maize yield increases that range from $65 \%$ in the $\mathrm{Gu}$ season to $124 \%$ in the Deyr season [14]. With proper crop management, some estimated yield increases are even greater, ranging from four to six-fold increases for maize and three-fold increases for sorghum [13]. Perhaps more importantly, these techniques have proven to be cost effective and increase net farm income [14]. 


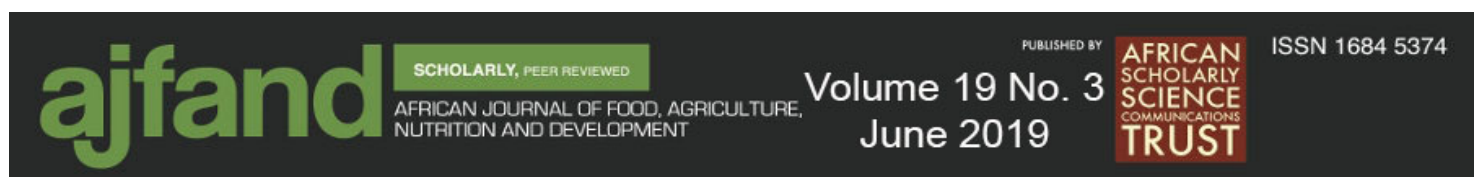

\section{CONCLUSION}

In both per capita and absolute terms, cereal production in Somalia has failed to improve and was highly volatile between 1961 and 2012. In that time, cereal imports were similarly unpredictable annually and were unable to compensate for the lack of agricultural growth. The above study shows that, while immediate failures of domestic cereal production may have contributed to the disastrous 1992 and 2011 famines, those failures took place in the context of stagnant long-term production, year-to-year production volatility, an increasing dependence on cereal imports and food aid, and a ballooning population. The most direct path to food security in Somalia lies in increasing total domestic production and improving its year-to-year reliability. Recent research in the country has demonstrated that increasing total domestic production and improving its year-to-year reliability is achievable through the implementation of simple agricultural best management practices. 


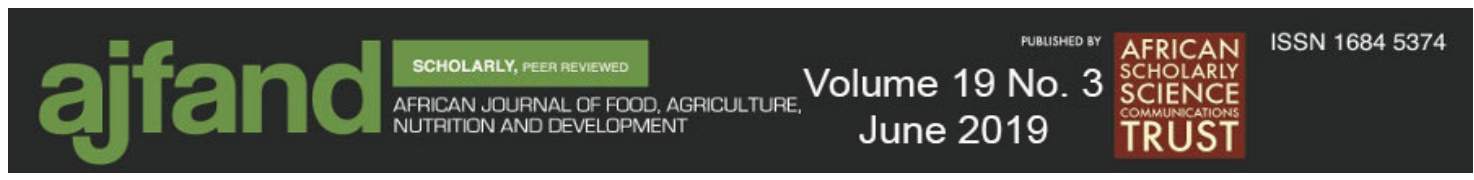

\section{REFERENCES}

1. Lewis IM A Modern History of the Somali: nation and state in the Horn of Africa. Ohio University Press, Athens. 2003.

2. Guha-Sapir $\mathbf{D}$ and $\mathbf{R}$ Ratnayake Consequences of ongoing civil conflict in Somalia: evidence for public health responses. PLoS medicine. 2009; 6(8): e1000108.

3. Moore P, Marfin A, Quenemoen L, Gessner B, Miller D, Toole M, and K Sullivan Mortality rates in displaced and resident populations of central Somalia during 1992 famine. The Lancet. 1993; 341(8850): 935-938.

4. Maxwell D and M Fitzpatricks The 2011 Somalia famine: Context, causes, and complications. Global Food Security. 2012; 1:5-12.

5. Ó Gráda C Famine: A Short History. Princeton University Press, Princeton. 2009; 24.

6. Checchi $\mathbf{F}$ and $\mathbf{W}$ Robinson Mortality among populations of southern and central Somalia affected by severe food insecurity and famine during 2010-2012. Food Security and Nutrition Analysis Unit, Somalia. Famine Early Warning System, Food and Agriculture Organization of the United Nations. 2013.

7. Ferris E and D Petz (Somalia: Drought + Disasters = Famine?). In: The Year that Shook the Rich: A Review of Natural Disasters in 2011. London, UK: The Brookings Institution and London School of Economics, Project on Internal Displacement. 2012; 3: 97-113.

http://www.brookings.edu/research/reports/2012/03/natural-disaster-review-ferris Retrieved September 10, 2018.

8. Gibson M Food Security-A Commentary: What Is It and Why Is It So Complicated? Foods. 2012; 1(1): 18-27. http://doi.org/10.3390/foods1010018.

9. Food and Agriculture Organization of the United Nations. Trade Reforms and Food Security: Conceptualizing the Linkages. Food and Agriculture Organization of the United Nations; Rome, Italy: 2003; 313.

10. What the World Eats. National Geographic Magazine. 2017. http://www.nationalgeographic.com/what-the-world-eats/ Accessed October 8, 2017.

11. World Bank Open Data. The World Bank Group. Washington D.C., USA. 2016.. http://data.worldbank.org Retrieved August 18, 2017.

12. Food and Agriculture Organization Corporate Statistical Database. Food and Agriculture Organization of the United Nations. Rome, Italy. 2017. http://www.fao.org/faostat/en/\#home Retrieved August 18, 2017. 


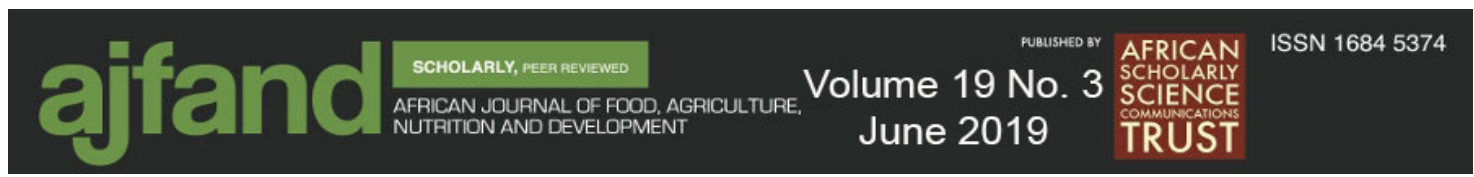

13. Somalia: Rebuilding Resilient and Sustainable Agriculture. Food and Agriculture Organization of the United Nations. 2018.

http://documents.worldbank.org/curated/en/781281522164647812/pdf/124651WP-P159009-PUBLIC-main-report.pdf Retrieved March 10, 2018.

14. Gavin R, Haji H, Jelinski $\mathbf{N}$ and $\mathbf{P}$ Porter An on-farm comparison of the agronomics and economics of irrigated maize production systems in the Somali Deyr season. African Journal of Agricultural Research. 2018; 13(23):1177-1185.

15. Food Tracker. World Food Programme Food Aid Information System. World Food Programme of the United Nations. 2017. http://www.wfp.org/fais/ Retrieved August 10, 2017.

16. Rembold F, Hodges R, Bernard M, Knipschild $\mathbf{H}$ and $\mathbf{O}$ Léo. The African postharvest losses information system (APHLIS). European Union, Luxembourg. 2011.

17. Population Estimation Survey Somalia. United Nations Population Fund. Nairobi, Kenya: UNFPA. 2014. http://somalia.unfpa.org/sites/default/files/pubpdf/Population-Estimation-Survey-of-Somalia-PESS-2013-2014.pdf. Retrieved August 20, 2017.

18. Subsistence Farming in Lower Shabelle Riverine Zone. Food Security and Nutrition Analysis Unit, Somalia. Food and Agriculture Organization of the United Nations. 2013.

19. Gavin R, Hussein $\mathbf{H}$, Jelinski $\mathbf{N}$ and $\mathbf{P}$ Porter On-farm Irrigated Maize Production in the Somali Gu Season. African Journal of Agricultural Research. 2018; 13(19):969-977.

20. Adam H and R Ford Somalia Toward a Revised Rural Development Strategy. Proceedings of the National Conference on Somalia's Rural Development Strategy. Somali Unit for Research on Emergencies and Rural Development. Mogadishu, Somalia. Clark University Program for International Development, Worcester, USA. 1986.

http://pdf.usaid.gov/pdf_docs/PNABG397.pdf Retrieved August 26, 2017.

21. Assefa Y, Roozeboom K, Thompson C, Schlegel A, Stone $L$ and J Lingenfelser Corn and Grain Sorghum Historical Yield, Area Harvested, and Price Trends In: Corn and Grain Sorghum Comparison. Academic Press, 2014:15-30. https://doi.org/10.1016/C2013-0-14435-2.

22. Mwangi WM Low use of fertilizers and low productivity in sub-Saharan Africa. Nutrient Cycling in Agroecosystems. 1996; 47(2):135-147. 